\title{
Risk Factor Empirical Research of PPP Projects Based on Factor Analysis Method
}

\author{
Hang Yin1,2, Yuan-Fu Li',3, Dong-Mei Zhao' \\ ${ }^{1}$ School of Economics and Management, Southwest Jiaotong University, Chengdu, China \\ ${ }^{2}$ Key Laboratory of High-speed Railway Engineering, Education Ministry of China, Chengdu, China \\ ${ }^{3}$ School of Civil Engineering, Southwest Jiaotong University, Chengdu, China \\ Email: yinhang@my.swjtu.edu.cn
}

Received 27 May 2015; accepted 21 June 2015; published 24 June 2015

Copyright (C) 2015 by authors and Scientific Research Publishing Inc.

This work is licensed under the Creative Commons Attribution International License (CC BY).

http://creativecommons.org/licenses/by/4.0/

(c) (i) Open Access

\begin{abstract}
As an innovative investment and financing system of urbanization and the key to the local financing platform to resolve the debt risk, PPP projects have great significance to the current Chinese economy. At present, domestic PPP projects lack of benefit sharing standard and the mechanism of risk-sharing and risk factor analysis is the premise of risk-sharing. Adopting the raw data of major risk factors by questionnaire investigation from a key domestic PPP project, and using SPSS and factor analysis method to do an empirical test, a financing risk index system is built. The results of the study also reveal that financing risk factors are the most important ones to a particular PPP project.
\end{abstract}

\section{Keywords}

PPP Projects, Risk Factors Analysis, Factor Analysis Method

\section{Introduction}

New type of urbanization will be important to expand domestic demand and realize economic structure strategic adjustment propeller of China. At the same time, it requires large capital investment. According to the estimation that urbanization rate in china will reach $60 \%$ in 2020 , the required investment will be about 42 trillion China Yuan, but there is still nearly 20 trillion local debt risk needed to be solved [1] [2]. Obviously, how to reasonably solve the funding problem is to keep healthy and rapid development of urbanization construction, and objective condition is not enough just relying on the government fiscal revenue. A way to solve the problem of financing is urgently needed.

In November 2013's national financial work conference, The Ministry of Finance held a meeting of PPP 
(Public Private Partnership). According to the concept given by the United Nations development program, PPP refers to the government, the for-profit businesses and nonprofit organizations based on a project to form a mutual cooperation relationship. Now PPP as a good way to solve new funding problem of urbanization has won national recognition, and relevant legislation and implementation of the work are in an orderly way.

In this paper, the method of questionnaire survey is used, a detailed investigation of the PPP project risk factors is conducted, and the current major risk factors for PPP projects in China are analyzed. Using factor analysis method to find the key indicators of the PPP project risks, the index evaluation system is built. And through the analysis of data, specific risk factors for PPP projects should been pay strong attention to can be find out.

\section{The Index System's Construction and Validation}

\subsection{The Construction of Index System with Variable Definitions Related Factors}

Based on the study of foreign PPP management experiences and typical PPP projects cases analysis both in China and abroad, the potential risk factors list for PPP projects has been built. Selected cases covered the mainstream which government uses PPP to construct, such as rail transportation, water conservancy engineering, bridge engineering, tunnel engineering, constructed engineering, environmental engineering, etc. On the basis of analysis of the PPP project cases both in China and abroad, refer to the PPP project risk classification which has been widely recognized by the academic community created by Akintoye and Bing from the university of Glasgow [3]-[6] to build the potential risk factors for PPP projects. There are 31 variable risk factors: Interest rate volatility $(\mathrm{C} 1)$, inflation $(\mathrm{C} 2)$, financial market downturn $(\mathrm{C} 3)$, project examination and approval, and permit delay (C4), monetary policy changes (C5), the industry policy fluctuations (C6), asset requisition or nationalization (C7), public decision-making is not sound attractive to investors (C8), project (C9), the feasibility of financing $(\mathrm{C} 10)$, poor construction technology $(\mathrm{C} 11)$, contract changes $(\mathrm{C} 12)$, material availability $(\mathrm{C} 13)$, the late design changes (C14), the construction cost overruns (C15), construction schedule delays (C16), frequent (C17) than expected maintenance, maintenance costs more than expected $(\mathrm{C} 18)$, poor operating performance $(\mathrm{C} 19)$, operating cost overruns (C20), operating income is lower than expected (C21), organization coordinated risk (C22), improper risk allocation (C23), the PPP project experience insufficiency (C24), accrual misallocation (C25), concept and basic differences between partners (C26), a lack of trust between partners (C27), meteorological conditions (C28), hydrological condition (C29), a design flaw (C30) and geological conditions (C31).

\subsection{Data Acquisition and Test Methods}

In this paper, the data from questionnaire, relying on the second ring highway PPP project of Chengdu which budgetary estimate is 28.5 billion. Respondents from project related institutions such as the government agencies, government financing platform company, project investment and financing company, design unit, contractor. Volume with seven semantic difference scale, its high variability of data covariance analysis of the structural equation model is more effective [7]. In the practical investigation and research, according to the characteristics of the different research object, using the fill in the questionnaire survey and the access type combination of investigation. The number of investigators meets the principle that it should be more than $3-5$ times of the table which contains the most questions. Investigators did not show spirit of weariness during the investigation process. Time for fill in the questionnaire is 13 minutes on average. Content is complete and effective and the number of questions is appropriate. Totally issued 160 questionnaires, recycling effective questionnaires 154, effective recovery rate was $96.25 \%$. In general, the structure and content of the questionnaire fullfill the predetermined requirement in the aspect of theory and the statistical test. After accurate statistical data from the recycling questionnaires, Using the factor analysis modules of SPSS to establish evaluation index system of PPP project risk. By analyzing the correlation between variables, convert multiple variables to fewer public factors. According to the principle that common factors' cumulative variance contribution rate should be more than $85 \%$ can divide Integrated original variables into $\mathrm{m}$ class. That is, to extract $\mathrm{m}$ class effective public factors from sample data, denoted as $\left(F_{1}, F_{2}, \cdots, F_{m}\right)$.

The model of factor analysis:

$$
X_{i}=a_{i 1} F_{1}+a_{i 2} F_{2}+\cdots+a_{i m} F_{m}+\varepsilon_{i},(i=1,2, \cdots, p)
$$

This suggests that attempts to use $m$ potential public factors $\left(F_{1}, F_{2}, \cdots, F_{m}\right)$ to explain the linear indicator 
variables $X_{i}$, in which coefficients $a_{i 1}, a_{i 2}, \cdots, a_{i m}$ called the factor loading, indicate the corresponding ability of common factors reflected by $X_{i} . \varepsilon_{i}$ is a special factor, indicate the parts $X_{i}$ can't been explained by $\mathrm{m}$ public factors, $\varepsilon_{i}$ can't been observed, generally assumed that $\varepsilon_{i} \sim N\left(0, \sigma_{i}^{2}\right)[8]$.

\section{Empirical Research}

First, turn sample data got from questionnaire survey into standardized matrix then use principal component analysis method to evaluate factor loadings, set factor loading thresholds as 0.7 , extracted 8 common factors: F1, F2, F3, F4, F5, F6, F7 and F8 to establish Factor loading matrix. Typically representative is not prominent, abstracted from the original factor is difficult to explain effectively, need to axis of the original factor loading matrix. Shaft after most of the item in each of the common factors will have a different factor of the load, so as to achieve the aim of eliminate interference and simplify data structure. This article used the maximum variation method to axis of the factor loading matrix.

Through analyzed the data SPSS output, a total of 13 common factors' characteristic value are greater than 1. The top eight common factors of the cumulative variance contribution rate has reached $86.247 \%$ which has reached the requirement of cumulative variance contribution rate is more than $85 \%$. The top eight common factors can better reflect the original index represents information so chose them as a comprehensive index of evaluation of the PPP project risks. After a shaft the factor loading matrix can clearly reflect the relevance between the top eight common factors and the original indexes, which is showed in Table 1.

Table 1. The factor loading matrix table after rotation.

\begin{tabular}{|c|c|c|c|c|c|c|c|c|}
\hline & F1 & $\mathrm{F} 2$ & F3 & F4 & F5 & F6 & F7 & F8 \\
\hline $\mathrm{C} 15$ & 0.924 & -0.028 & 0.035 & -0.122 & 0.054 & 0.114 & 0.050 & 0.187 \\
\hline $\mathrm{C} 16$ & 0.916 & -0.006 & 0.043 & -0.095 & 0.083 & 0.101 & 0.033 & 0.178 \\
\hline $\mathrm{C} 13$ & 0.886 & 0.007 & 0.025 & -0.186 & -0.034 & 0.098 & -0.065 & 0.082 \\
\hline $\mathrm{C} 14$ & 0.884 & 0.030 & 0.018 & -0.086 & 0.033 & 0.129 & 0.059 & 0.055 \\
\hline C11 & 0.824 & -0.059 & -0.007 & -0.170 & -0.087 & 0.054 & 0.110 & 0.120 \\
\hline $\mathrm{C} 12$ & 0.780 & -0.052 & -0.007 & -0.010 & -0.048 & 0.322 & 0.127 & 0.013 \\
\hline $\mathrm{C} 22$ & -0.103 & 0.921 & -0.065 & -0.042 & -0.092 & -0.124 & 0.061 & -0.044 \\
\hline $\mathrm{C} 24$ & -0.008 & 0.917 & -0.153 & -0.015 & -0.189 & -0.007 & -0.015 & -0.042 \\
\hline $\mathrm{C} 23$ & 0.024 & 0.908 & -0.126 & 0.089 & -0.127 & -0.027 & 0.041 & -0.068 \\
\hline $\mathrm{C} 25$ & -0.042 & 0.899 & -0.195 & -0.034 & -0.174 & -0.006 & 0.072 & 0.053 \\
\hline $\mathrm{C} 26$ & 0.023 & 0.860 & -0.122 & 0.181 & -0.070 & 0.014 & 0.073 & -0.083 \\
\hline $\mathrm{C} 27$ & 0.005 & -0.004 & 0.905 & 0.036 & 0.075 & 0.027 & 0.024 & 0.026 \\
\hline $\mathrm{C} 20$ & 0.017 & -0.176 & 0.899 & -0.004 & 0.179 & 0.007 & -0.005 & 0.044 \\
\hline $\mathrm{C} 21$ & 0.087 & -0.190 & 0.880 & 0.035 & 0.191 & -0.049 & 0.102 & 0.121 \\
\hline C19 & 0.024 & -0.316 & 0.825 & -0.051 & 0.131 & -0.032 & 0.089 & 0.084 \\
\hline C18 & 0.018 & -0.374 & 0.779 & -0.034 & 0.145 & -0.132 & 0.101 & 0.003 \\
\hline $\mathrm{C} 17$ & -0.026 & 0.160 & 0.753 & 0.053 & 0.152 & 0.215 & -0.114 & -0.074 \\
\hline C6 & -0.134 & 0.043 & 0.028 & 0.898 & -0.027 & -0.055 & 0.061 & -0.121 \\
\hline $\mathrm{C} 7$ & -0.180 & -0.007 & -0.015 & 0.897 & 0.013 & -0.165 & 0.037 & 0.034 \\
\hline $\mathrm{C} 8$ & -0.197 & 0.024 & 0.047 & 0.845 & -0.041 & -0.198 & 0.095 & 0.136 \\
\hline $\mathrm{C} 5$ & -0.104 & 0.141 & -0.016 & 0.779 & 0.002 & -0.076 & 0.137 & -0.421 \\
\hline $\mathrm{C} 3$ & 0.002 & -0.223 & 0.254 & -0.025 & 0.920 & 0.097 & 0.003 & 0.038 \\
\hline $\mathrm{C} 2$ & 0.002 & -0.223 & 0.254 & -0.025 & 0.920 & 0.097 & 0.003 & 0.038 \\
\hline $\mathrm{C} 1$ & -0.008 & -0.206 & 0.281 & -0.008 & 0.871 & 0.045 & -0.052 & -0.057 \\
\hline $\mathrm{C} 10$ & 0.241 & -0.038 & 0.006 & -0.267 & 0.101 & 0.827 & 0.089 & 0.249 \\
\hline $\mathrm{C} 9$ & 0.208 & -0.033 & 0.027 & -0.242 & 0.126 & 0.816 & 0.121 & 0.238 \\
\hline $\mathrm{C} 29$ & 0.452 & -0.083 & 0.010 & -0.079 & 0.050 & 0.773 & 0.022 & 0.047 \\
\hline $\mathrm{C} 28$ & 0.119 & 0.097 & 0.068 & 0.131 & -0.020 & 0.087 & 0.967 & -0.029 \\
\hline $\mathrm{C} 4$ & 0.119 & 0.097 & 0.068 & 0.131 & -0.020 & 0.087 & 0.967 & -0.029 \\
\hline $\mathrm{C} 30$ & 0.301 & -0.138 & 0.075 & -0.123 & 0.048 & 0.248 & 0.059 & 0.836 \\
\hline $\mathrm{C} 10$ & 0.351 & -0.025 & 0.106 & -0.055 & -0.038 & 0.241 & -0.127 & 0.811 \\
\hline C9 & 0.924 & -0.028 & 0.035 & -0.122 & 0.054 & 0.114 & 0.050 & 0.187 \\
\hline
\end{tabular}


Observe the index relationship in table 1 we can see common factor $\mathrm{F} 1$ has high load in $\mathrm{C} 15, \mathrm{C} 16, \mathrm{C} 13, \mathrm{C} 14$, $\mathrm{C} 11$ and $\mathrm{C} 12$, most obvious in $\mathrm{C} 15, \mathrm{C} 16$ and $\mathrm{C} 13$. From the index system represented by those variables we can see these indexes are all about risk factors in construction phase of PPP projects so we name the common factor "construction risk factor" (variance contribution rate is $25.993 \%$ ).

Common factor F2 has bigger load in C22, C24, C23, C25 and C26 and the load are all above 0.85 which have strong ability of explanation. Common factor F2 can express $20.447 \%$ sample characteristics of the original data. These indicators are all about possible relationship risks between collaborative subjects of PPP projects so we name the common factor "relationship risk factor".

In the same way, we named F3, F4, F5, F6, F7 and F8 based on their high load factors (by the rule that factor load is more than 0.7 ), which is showed in Table 2.

Table 2. Common factors' naming and contains variables.

\begin{tabular}{|c|c|c|}
\hline Factors & Name & Variables common factor contains \\
\hline \multirow{6}{*}{ F1 } & \multirow{6}{*}{ Construction risk factor } & Construction cost overruns $\mathrm{C} 15$ \\
\hline & & Construction schedule delay $\mathrm{C} 16$ \\
\hline & & Material availability $\mathrm{C} 13$ \\
\hline & & Late design changes $\mathrm{C} 14$ \\
\hline & & Poor construction technology $\mathrm{C} 11$ \\
\hline & & Modification of contract $\mathrm{C} 12$ \\
\hline \multirow{6}{*}{$\mathrm{F} 2$} & \multirow{6}{*}{ Relationship risk factor } & Organization and coordination risks $\mathrm{C} 22$ \\
\hline & & Lack of PPP projects experience C24 \\
\hline & & Improper risk allocation $\mathrm{C} 23$ \\
\hline & & Improper distribution of power and responsibility $\mathrm{C} 25$ \\
\hline & & Concept and technical differences between partners C26 \\
\hline & & Lack of trust between partners $\mathrm{C} 27$ \\
\hline \multirow{5}{*}{ F3 } & \multirow{5}{*}{ Operational risk factor } & Operating cost overruns $\mathrm{C} 20$ \\
\hline & & Operating income is lower than expected C21 \\
\hline & & Poor operating performance C19 \\
\hline & & Maintenance costs are higher than expected C18 \\
\hline & & Maintain frequent than expected $\mathrm{C} 17$ \\
\hline \multirow{4}{*}{ F4 } & \multirow{4}{*}{ Political risk factor } & Industry policy changes $\mathrm{C} 6$ \\
\hline & & The expropriation of assets or nationalized $\mathrm{C} 7$ \\
\hline & & Public decision-making is not sound C8 \\
\hline & & Monetary policy changes $\mathrm{C} 5$ \\
\hline \multirow{3}{*}{ F5 } & \multirow{3}{*}{ Environmental risk factor } & Geological conditions $\mathrm{C} 31$ \\
\hline & & Meteorological condition $\mathrm{C} 28$ \\
\hline & & Hydrologic condition C29 \\
\hline \multirow{3}{*}{ F6 } & \multirow{3}{*}{ Macroeconomic risk factor } & The depression of financial markets $\mathrm{C} 3$ \\
\hline & & Inflation rate fluctuations $\mathrm{C} 2$ \\
\hline & & Interest rate uncertainty $\mathrm{C} 1$ \\
\hline \multirow{2}{*}{ F7 } & \multirow{2}{*}{ Design risk factor } & Delay of project examination and approval and permits $\mathrm{C} 4$ \\
\hline & & Design flaw C30 \\
\hline \multirow{2}{*}{ F8 } & \multirow{2}{*}{ Financing risk factor } & The feasibility of financing $\mathrm{C} 10$ \\
\hline & & Project attractive to investors C9 \\
\hline
\end{tabular}


The conclusion in Table 2 is that the risk evaluation index system for the second ring highway PPP project of Chengdu which has been checked by factor analysis method. At the same time, the application of research methods of this article can also identify the risk factors need to be focused on of every other PPP projects.

\section{Conclusion}

Based on the study of foreign PPP management experiences and typical PPP projects cases analysis both in China and abroad, the potential risk factors list for PPP projects has been built. Relying on the second ring highway PPP project of Chengdu, a questionnaire survey is carried out. Using factor analysis method to analysis the statistical data of the questionnaire then screened and named common factors as: construction risk factor, cooperation relationship risk factor, operational risk factor, policy risk factor, environment risk factor, political risk factor, design risk factor, macroeconomic risk factor and financing risk factor. On this basis, the index system of PPP project risks is constructed. The PPP project risk allocation decisions in China provide a certain basis. At the same time, the results also reveal that the specific risk factors for PPP projects need to be focused on. But this article doesn't discuss the relationship among common factors which will be improved in the future research.

\section{References}

[1] Chan, K.W. (2014) China's Urbanization 2020: A New Blueprint and Direction. Eurasian Geography and Economics, 55, $1-9$.

[2] Li, K.-Q. (2014) Government Work Report-Key Work in 2014. Contemporary Social Vision, 3, 2-3.

[3] Bing, L., Akintoye, A., Edwards, P.J., et al. (2005) The Allocation of Risk in PPP/PFI Construction Projects in the UK. International Journal of Project Management, 23, 25-35. http://dx.doi.org/10.1016/j.ijproman.2004.04.006

[4] Daube, D., Vollrath, S. and Alfen, H.W. (2008) A Comparison of Project Finance and the Forfeiting Model as Financing Forms for PPP Projects in Germany. International Journal of Project Management, 26, 376-387. http://dx.doi.org/10.1016/j.ijproman.2007.07.001

[5] Liu, X.P. and Wang, S.Q. (2006) Risk Allocation Principles and a Framework for Risk Allocation of PPP. Construction Economy, 280, 59-63.

[6] Cong, H., Zhang, Y. and Ding, J. (2007) Research on Application of PPP Mode in Subway Project Financing. Construction Management Modernization, 10, 41-43.

[7] Allen, D.R. and Wilburn, M. (2002) Linking Customer and Employee Satisfaction to the Bottom Line. American Society for Quality, Milwaukee.

[8] Hatcher, L. and O’Rourke, N. (2014) A Step-by-Step Approach to Using SAS for Factor Analysis and Structural Equation Modeling. SAS Institute, Cary. 